\title{
A New Variant Nummular Headache: Large Diameter Accompanied with Bitrigeminal Hyperalgesia and Successful Treatment with Carbamazepine
}

\section{Yeni Varyant Nummuler Başağrnsı: Bitrigeminal Hiperaljeziyle Birlikte Büyük Çap ve Karbamazepinle Başarılı Tedavi}

\author{
Yu-Hong MAN ${ }^{1,2}$, Ting-Min $\mathrm{YU}^{2}$, Li-Sen $\mathrm{LI}^{3}$, Gang $\mathrm{YAO}^{2}$, Xi-Jing $\mathrm{MAO}^{2}$, Jiang WU \\ ${ }^{1}$ The First Hospital of Jilin University, Department of Neurology, Changchun, China \\ 2The Second Hospital of Jilin University, Department of Neurology, Changchun, China \\ ${ }^{3}$ China-Japan Union Hospital of Jilin University, Department of Hand Surgery, Changchun, China
}

Correspondence address: Ting-Min YU / E-mail: myh1996@163.com

\begin{abstract}
Nummular headache $(\mathrm{NH})$ is defined as a focal head pain that is exclusively felt in a small area, which is typically $1-6 \mathrm{~cm}$ in diameter. Neurological examinations are normal in all patients, but this report describes a new variant. A patient was identified who presented with focal head pain that was approximately $8 \mathrm{~cm}$ in diameter and bitrigeminal hyperalgesia on neurological examination. Treatment with carbamazepine provided significant analgesic relief in terms of both the frequency and intensity of pain. The findings enlarge the clinical diversity of this headache disorder. The pathogenic mechanisms of $\mathrm{NH}$ may be similar to trigeminal neuralgia in particular patients.
\end{abstract}

KEYWORDS: Nummular headache, Hyperalgesia, Analgesia, Carbamazepine

öz

Nummuler başağrısı tipik olarak 1-6 cm çapında küçük bir alanda hissedilen fokal başağrısı olarak tanımlanır. Nörolojik incelemeler tüm hastalarda normaldir ama bu rapor yeni bir varyant tanımlamaktadır. Başvuran bir hastada yaklaşık $8 \mathrm{~cm}$ çapında fokal başağrısı ve nörolojik muayenede bitrigeminal hiperaljezi saptandı. Karbamazepin ile tedavi ağıının hem sıklığı hem şiddeti açısından önemli analjezik düzelme sağladı. Bulgular bu başağrısı bozukluğunun klinik çeşitliliğini yansıtmaktadır. Nummuler başağrısı için patolojik mekanizmalar belirli hastalarda trigeminal nevraljiye benzeyebilir.

ANAHTAR SÖZCÜKLER: Nummuler başağrısı, Hiperaljezi, Analjezi, Karbamazepin

\section{INTRODUCTION}

Nummular headache $(\mathrm{NH})$ is a well-defined clinical condition characterized by local pain that is in a small (typically $1-6 \mathrm{~cm}$ diameter), rounded or elliptical area of the head. The pain remains confined to this coin-shaped area and does not change in size or shape over time. It is of mild to moderate intensity and can be either continuous or intermittent. After the first description of this condition in 13 patients in 2002 (23), it has been included in the classification of the research diagnostic criteria of the International Classification of Headache Disorders, $2^{\text {nd }} E d$. (Table I) (18). At present, more than 100 additional cases have been reported across many different countries $(1,3-6,8,10-17,19-22,25,26$, 28 32), of which some have shown different features. In this paper, another new clinical feature is described, which was identified in a patient who was admitted to the Department of Neurology at the Second Hospital of Jilin University in April 2010. This report will highlight the features of this case that increase the clinical diversity of $\mathrm{NH}$.

\section{CASE REPORT}

A 59-year-old man presented with 1 month history of headache that consisted of lancinating pain attacks that lasted for several seconds. These attacks were described as paroxysmal, electric shock-like pain that were similar to those described in trigeminal or occipital neuralgia. The pain was non-radiating and could be evoked by touching the area in question. This area covered the area of an $8 \mathrm{~cm}$ diameter circle in the right temporal-parietal region, without side shift (Figure 1). The pain was of a severe intensity, fluctuating around eight out of ten, and was not associated with any localized or generalized autonomic symptoms. The patient had a past medical history of significant coronary artery disease and hypertension. He had no history of headaches.

Tender pressure points were found in the symptomatic area. Bitrigeminal hyperalgesia was present, but otherwise neurological and physical examinations were normal. Blood tests, X-rays and ECG were also normal. The basal ganglia 
Table I: Proposed ICHD-II Diagnostic Criteria for A13.7.1, Nummular Headache

Description:

Pain is in a small circumscribed area of the head in the absence of any lesion of the underlying structures.

Diagnostic criteria:

A Mild to moderate head pain fulfilling criteria $B$ and $C$

B Pain is felt exclusively in a rounded or elliptical area, typically $2-6 \mathrm{~cm}$ in diameter

C Pain is chronic and either continuous or interrupted by spontaneous remissions lasting weeks to months

D Not attributed to another disorder

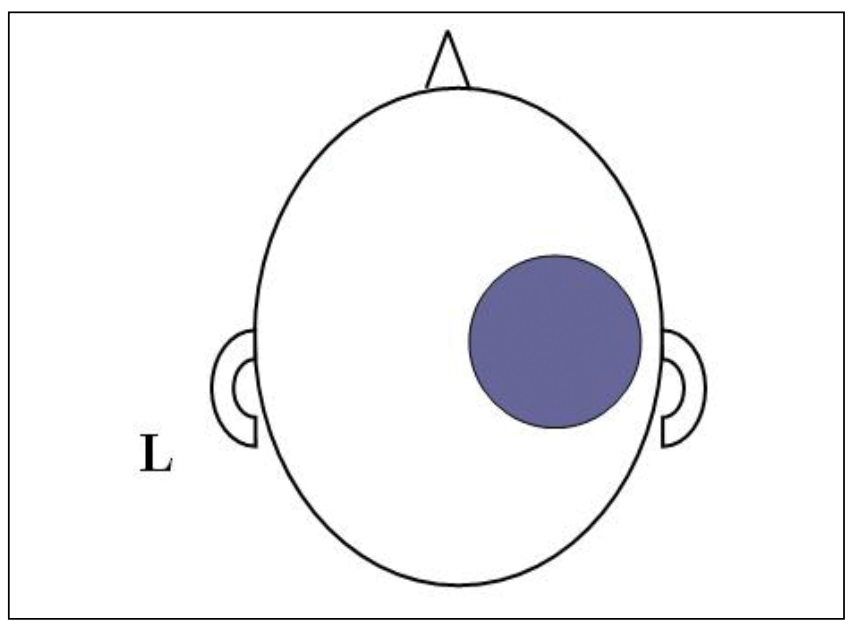

Figure 1: Location and relative size of the painful area in the case.

and corona radiata had multiple bilateral punctiform and lamellar low density areas on the brain CT scan. Right- and left-sided carotid artery stenoses were present (10\% and $20 \%$, respectively) on the head and neck computed tomographic angiography (CTA) scan. The patient had not taken any symptomatic or preventive medications to alleviate the pain.

The changes on the brain CT scan and the head and neck CTA suggested a diagnosis of lacunar infarction. However, there were some differences between this case and the diagnostic criteria for $\mathrm{NH}$. Firstly, the diameter of the circular region of pain measured $8 \mathrm{~cm}$, which exceeded the typical diameter of 2-6 cm in $\mathrm{NH}$. Secondly, there were signs of bitrigeminal hyperalgesia, yet most patients with $\mathrm{NH}$ have normal neurological examinations, apart from their symptomatic area. However, we believe the features of this case overlapped with the diagnostic criteria of $\mathrm{NH}$, as the area of pain was limited to a circular area over the right temporalparietal region, which did not change in shape and size in one month. Lacunar infarction is not usually associated with such headaches. Therefore, the diagnosis of $\mathrm{NH}$ was made.

The patient was treated with oral carbamazepine at a dose of $100 \mathrm{mg}$ twice daily. The dose was increased to three times daily after seven days, since the pain remained unchanged. It was then changed again to $200 \mathrm{mg}$ in the morning and $100 \mathrm{mg}$ at noon and night after nine days. The pain reduced over this time, as well as the intensity and incidence of the headaches. There were no significant signs on neurological examination and the bitrigeminal hyperalgesia resolved after 14 days. The same dosages were given for a further 10 days and then stopped. The patient was discharged the next day and remained pain free over six-month follow-up period.

\section{DISCUSSION}

Since the original description by Pareja, many reports of cases have enlarged the clinical knowledge of $\mathrm{NH}$. It is now known that the lancinating pain attacks may be the only manifestation of $\mathrm{NH}$ (27). NH may appear in two distinct areas in the same patient. The symptomatic areas may be located on one side or both sides of the head. The pain may emerge at the same time or follow a different course in each of the affected areas (7). Some patients have shown trophic changes within the painful area (25). These descriptions might be considered to be the symptomatic form of $\mathrm{NH}$. In the present case, a new clinical expression of $\mathrm{NH}$ is reported, with features of a short duration, a large diameter in the right temporalparietal region, lancinating pain attacks that only lasted for seconds in that area, and bitrigeminal hyperalgesia on the neurological examination.

As a primary headache form, the painful area may be localized in any part of the head, but is usually located in the parietal region; the pain does not change in shape or size over time. However, the affected area in this patient was limited to the right temporal-parietal region. The shape of the area of $\mathrm{NH}$ pain in this patient was circular, did not change in form and had a diameter that measured approximately $8 \mathrm{~cm}$. The intensity of pain was severe, which was similar to the cases already reported $(3,4,8,13,14,19,25,26)$, although it is worth noting that $\mathrm{NH}$ pain is typically described as mild to moderate $(18,23)$. The majority of the pain quality of $\mathrm{NH}$ has been described as pressing, burning or dull $(8,11,19,23,24$, $26,29,32$ ). Lancinating pain attacks, without baseline pain, as the only manifestation ( 2 patients) have only previously been reported by Ruscheweyh et al (27); the present case brings this total to three. Neurological examination of patients with $\mathrm{NH}$ is usually normal, except inside the painful area, which typically exhibit tenderness, paresthesia, hyperesthesia and allodynia. This present case is the first in which bitrigeminal hyperalgesia was found as the only sign on the neurological examination. After treatment with instigated with carbamazepine, the pain gradually resolved and had disappeared midway through the course of treatment. 
The treatment of $\mathrm{NH}$ is difficult. Different drugs and methods have been used for some cases, such as paracetamol, nonsteroidal anti-inflammatory drugs, indomethacin, gabapentin, duloxetine, topiramate, amitriptyline, nortriptyline, clomipramine, local botulinum toxin, local subcutaneous lidocaine application, local infiltrations and auriculotemporal nerve blocks, and local transcutaneous electric nerve stimulation. Some may reduce pain, but the most effective treatments do not require repeated applications. The new treatment option for $\mathrm{NH}$ is the use of local botulinum toxin (2); however, there are some different opinions with regards to its efficacy (9).

This case study highlights that carbamazepine may be a successful treatment option for $\mathrm{NH}$. The reason may be due to the type of pain quality. The patient described in this case presented with lancinating pain attacks, such as those encountered in trigeminal or occipital neuralgia. This new finding is interesting as the etiology of $\mathrm{NH}$ has yet to be fully described. Possible mechanisms might include neuropathy of a terminal branch of a cutaneous scalp nerve and focal, nociceptive-type pain that stems from epicranial tissues (11, 26). The manifestation of electric-shock-like pain paroxysms without continuous pain, in this case, is termed as the terminal branch neuropathy hypothesis. The peripheral nerve lesion should be along the peripheral nerve in either its extracranial or intracranial course but does not have to be restricted to within the painful area. This hypothesis has been challenged because, in some cases, the painful area extends across the midline and subcutaneous infiltration of the painful area with local anesthesia is unsuccessful in reducing pain in the majority of cases. However, the successful treatment of the pain in the present case does support this hypothesis. The pathogenic mechanisms of $\mathrm{NH}$ may be similar to that of trigeminal neuralgia in some patients.

The case presented in this paper is a new variation of the clinical presentation of $\mathrm{NH}$. It was a large diameter $(8 \mathrm{~cm})$, accompanied by lancinating pain attacks and presented with bitrigeminal hyperalgesia on neurological examination. The successful treatment with carbamazepine alone offers an insight into the pathological mechanisms that underlie $\mathrm{NH}$ and gives some guidance as to its therapeutic treatment.

\section{REFERENCES}

1. Álvaro LC, García JM, Sádaba F, Cortina C: Cefalea numular: Es siempre una cefalea primaria? Neurología 22:713-714, 2007 (abstract)

2. Ashkenazi A, Silberstein S: Is botulinum toxin useful in treating headache? Yes. Current Treatment Options in Neurology 11:18-23, 2009

3. Bao $Y Q$, Huang $Y$, Tian $X L$, Zhong S, Zhu KY: Nummular headache: Eight new cases and therapeutic results in China. Cephalalgia 27:688, 2007 (abstract)

4. Barriga FJ, Hernández T, Pardo J, Sánchez C, Barón M, Dobato JL: Cefalea numular: Serie prospectiva de 20 nuevos casos. Neurologia 19:463-555, 2004 (abstract)
5. Cohen GL: Nummular headache: What denomination? Headache 45:1417-1418, 2005

6. Cuadrado ML, Valle B, Barriga FJ, Fernández-de-las- Peñas $C$ Pareja JA: Cefalea numular bilateral: caso princeps. Neurología 22:579, 2007 (abstract)

7. Cuadrado ML, Valle B, Fernández-de-las-Peñas $C$, Barriga FJ, Pareja JA: Bifocal nummular headache: The first three cases. Cephalalgia 29:583-586, 2009

8. Dach F, Speciali J, Eckeli A, Rodrigues GG, Bordini CA: Nummular headache: Three new cases. Cephalalgia 26: 1234-1237, 2006

9. Dusitanond P, Young W: Botulinum toxin type A's efficacy in nummular headache. Headache 48:1379, 2008

10. Evans RW: Case studies of uncommon headaches. Neurol Clin 24:347-362, 2006

11. Evans RW, Pareja JA: Nummular headache. Headache 45: 164-165, 2005

12. Fawad A, Weatherby SJ: Nummular headache. J Headache Pain 7:S3, 2006 (abstract)

13. Grosberg BM, Solomon S, Bigal ME, Lipton RB: Nummular headache and the International Classification of Headache Disorders (ICHD-2). Neurology 66(Suppl. 2):A178, 2006 (abstract)

14. Grosberg BM, Solomon S, Lipton RB: Nummular headache. Curr Pain Headache Rep 11:310-312, 2007

15. Guerrero AL, Martín-Polo J, Tejero MA, Gutiérrez F, Iglesias F, Sánchez-Barranco F: Representación de lacefalea numular en una consulta general de Neurología. Neurología 22:716, 2007 (abstract)

16. Guillem A, Barriga FJ, Giménez-Roldán S: Nummular headache secondary to an intracranial mass lesion. Cephalalgia 27: 943-944, 2007

17. Guillem A, Giménez-Roldán S: Cefalea numular sintomática. Neurología 18:613, 2003 (abstract)

18. Headache Classification Subcommittee of the International Headache Society: The International Classification of Headache Disorders, 2nd ed. Cephalalgia 24(Suppl. 1): 9-160, 2004

19. Kraya T, Gaul C: Nummular headache: Until now a little known disorder. Nervenarzt 79:202-205, 2008

20. Mathew NT, Kailasam J, Meadors L: Nummular headache responds to botulinum toxin type a (bonta); experience in four cases. Cephalalgia 26:1378, 2006 (abstract)

21. Mathew NT, Kailasam J, Meadors L: Botulinum toxin type A for the treatment of nummular headache: Four case studies. Headache 48:442-447, 2008

22. Monzillo PH, Lima Neto MM, Sanvito $W L$, Rodrigues da Costa A, Saab VM: Cefaléia numular: Relato de caso. Arq Neuropsiquiatr 62:903-905, 2004

23. Pareja JA, Caminero AB, Serra J, Barriga FJ, Barón M, Dobato JL, Vela L, Sanchez del Rio M: Nummular headache: A coinshaped cephalalgia. Neurology 58:1678-1679, 2002

24. Pareja JA, Cuadrado ML, Fernandez-de-las PC, Nieto C, Sols M, Pinedo F: Nummular headache with trophic changes inside the painful area. Cephalalgia 28:186-190, 2007 
25. Pareja JA, Cuadrado ML, Fernández-de-las Peñas C,Nieto $C$, Sols $M$, Pinedo F: Nummular headache with trophic changes inside the painful area. Cephalalgia 28:186-190, 2008

26. Pareja JA, Pareja J, Barriga FJ, Barón M, Dobato JL, Pardo J, Sanchez C, Vela L: Nummular headache: A prospective series of 14 new cases. Headache 44:611-614, 2004

27. Ruscheweyh R, Buchheister A, Gregor N, Jung A, Evers S: Nummular headache: Six new cases and lancinating pain attacks as possible manifestation. Cephalalgia 30:249-253, 2010

28. Seo MW, Park SH: Botulinum toxin treatment in nummular headache. Cephalalgia 25:991, 2005 (abstract)
29. Trucco M: Nummular headache: Another case treated with gabapentin. J Headache Pain 8:137-138, 2007

30. Trucco M, Del Conte L, Mainardi F, Perego G, Zanchin G: Successful treatment of a case of nummular headache with gabapentin. Cephalalgia 25:1199, 2005 (abstract)

31. Trucco M, Mainardi F, Perego G, Badino R, Zanchin G: Nummular headache: Case report and first therapeutic proposal. J Headache Pain 5(Suppl. 1):S37, 2004 (abstract)

32. Trucco M, Mainardi F, Perego G, Zanchin G: Nummular headache: First Italian case and therapeutic proposal. Cephalalgia 26:354-356, 2006 